\title{
Sergel in Naples and Pompeii: an Artistic Station in the Dark
}

\author{
Tomas MacsotaY*
}

Sergel in Naples and PompeiI: an Artistic Station in the Dark

\begin{abstract}
This contribution considers eighteenth-century visits to the antiquarian collections in Naples in the context of recent accounts of neoclassical art, and in particular Andrei Pop's reading of it through his introduction of the notion of "Neopaganism". The article argues that visits to Portici and the excavations at Herculaneum and Pompeii have been improperly amalgamated with the Roman study journey undertaken by artists and tourists. Noting the novelty and excitement of the archeological findings, but also the tight control on visitors and strict prohibition of any form of copy that signified the "extraction" of images of the Neapolitan treasures, the article argues that artists' visits to collections of antiquities must be treated as an anomaly in the study regime. The contribution draws from several records of visits, highlighting a small artists' excursion that included the Swedish sculptor Johan Tobias Sergel. In such records, but also in Sergel's sculpture, it finds evidence for the idea that Naples can be framed in terms of the budding fascination with a violent antiquity and with "natural" drives accompanying the rise of "Neopaganism" in the late 1760s. The intimate nature of some of the objects recovered, along with the dramatic relationship to the drama of sudden death and the sense of history having been "cancelled out" for the buried towns, made it difficult to sustain traditional attitudes of "admiration" for antique models.
\end{abstract}

\section{SERgel a NÀPols i PoMpeia: UNA ESTACió ARTísticA A LA Foscor}

\section{RESUM}

Aquesta contribució analitza la visita a les col-leccions d'antiguitats a Nàpols durant el segle XVIII a partir d'una lectura creuada amb estudis recents de l'art neoclàssic, i en particular la interpretació que d'ell en fa Andrei Pop en introduir el seu concepte de «neopaganisme». L'article argumenta que les visites a Portici i a les excavacions d'Herculà i Pompeia s'han amalgamat de manera tendenciosa amb el viatge d'estudis d'artistes i turistes a Roma. Notant la novetat i la commoció creada per les troballes arqueològiques, però també l'estricte control sobre els visitants i la prohibició a tot tipus de còpia que permutés «extreure» imatges dels tresors napolitans, l'article argumenta que les visites dels artistes a les colleccions d'antiguitats han de ser tractades com una anomalia en el règim d'estudi. La contribució es basa en diverses notes de visites, destacant una petita excursió d'artistes a la qual es va unir l'escultor suec Johann Tobias Sergel. Aquestes anotacions, però també l'escultura de Sergel, aporten una evidència que permet establir la hipòtesi que Nàpols es va convertir en sòl fèrtil per a la incipient fascinació per una antiguitat violenta i pels impulsos «naturals» que acompanyen el sorgiment del «neopaganisme» a la fi de la dècada de 1760 . La naturalesa íntima d'alguns dels objectes recuperats, juntament amb l'associació dramàtica de la mort sobtada, així com la idea que la història no va
* The research for this article was carried out under the RYC-2015-18371 (Ministerio de Economía y Competitividad) program. I wish to issue a particular word of acknowledgement to the anonymous reader of this article for her or his invaluable comments and suggestions. The ACAF/ART seminar Italia: Ida y Vuelta ("Italy: Round Trip"), Faculty of Geography and History, Universitat de Barcelona (9 May 2018), and a paper entitled Natural

Casting. Time and ImageTransmission in the Neapolitan sites and collections $c$. 1750-90, delivered for the Bilderfahrzeuge conference Images on the Move at Warburg House, London (11-12 May 2018) elicited responses that are echoed in the current contribution. 
transcórrer per a les ciutats ja soterrades, van fer difícil mantenir les actituds tradicionals d'«admiració» pels models antics.

Macsotay, T., "Sergel in Naples and Pompeii: an Artistic Station in the Dark", Acta/Artis. Estudis d'Art Modern, 6, 2018, pp. 113-129

KEYwords: Neoclassical sculpture, Naples, Pompeii, Grand Tour, reception of classical antiquity, Neopaganism, images of violence

PARAUles ClaU: Escultura neoclàssica, Nàpols, Pompeia, Grand Tour, recepció de l'antiguitat, neopaganisme, imatges de violència

\section{INTRODUCTION}

In 1994, the Nationalmuseum in Stockholm purchased a notebook and diary kept by the Swedish sculptor Johann Tobias Sergel (1740-1814) during the first years of his study journey to Rome. For the length of three weeks in October of 1768, Sergel wrote in his journal of his viewings in Naples and the recent excavations along the Gulf of Naples (figure 1). An English translation of Sergel's notebook is not available, but in 2016 the Portici and Pompeii passages were specially translated and commented by Marie Leander Touati and Ulf Cederlöf for the exhibition catalogue Returns to Pompeii. Interior Space and Decoration Documented and Revived $18^{\text {th }}-20^{\text {th }}$ Century. ${ }^{1}$ To judge by the evidence of other artists' correspondence and diaries, Sergel left us with a rare personal account of the Neapolitan and Vesuvian visit, matched by few others for the second half of the eighteenth century. Part of that uniqueness stems from the fact that for Sergel, Naples functions as an early and influential episode, rather than as a curtain fall, of the Roman sojourn.

Sergel's newly available account reminds us of the layered and fragile documentary basis of the purposes and pathways of the Italian study journey in the eighteenth century, which deserves to be considered here as a new opportunity to reflect on the practical and cultural aspects of artistic identity and engagement with the antique. Accounts of artists' lives on the visit to Italy have tended to lend excessive credibility to the received notion of the introverted artist on a youthful sentimental journey, obsessed with discovering an antiquity conceived as an ethereal ideal. In doing so, it has obscured evidence of the oscillating and arbitrary conditions attending to identifications with the antique. Particularly for sculptors like Sergel, this association to an imaginary antiquity had a marked collective quality, and was conditioned by commerce, livelihood and the physical realities of socio-political incertitude and Roman studio practice. ${ }^{2}$ Through a number of witness accounts of the Neapolitan site more or less contemporary to Sergel's, the following pages will underline the difficulties and contingencies attending to the specific experiences an artist could harvest around 1768 in the subtly changing terrain of Pompeii and Portici. Some of these have been widely noted, no less so by Leander Touati and

1. See Leander Touati, A.-M.; CederlöF, U., "Observations on the Museums in Portici and the Vesuvian Sites Made by Two Swedish Professionals in 1756 and 1768, Respectively”, in HaLes, S.; LeANDER Touati, A.-M. (eds.), Returns to Pompeii. Interior Space and Decoration Documented and Revived $18^{\text {th }}-20^{\text {th }}$ Century, exh. cat., Nationalmuseum, Stockholm. Stockholm: Swedish Institute in Rome, 2016, pp. 151-165. Many thanks to Anne-Marie Leander Touati for facilitating access to this catalogue.

2. Macsotay, T., "Close Up and Far Away”, in idem (ed.), Rome, Travel, and the Sculpture Capital (1770-1820). London: Routledge, 2016, pp. 1-27. 


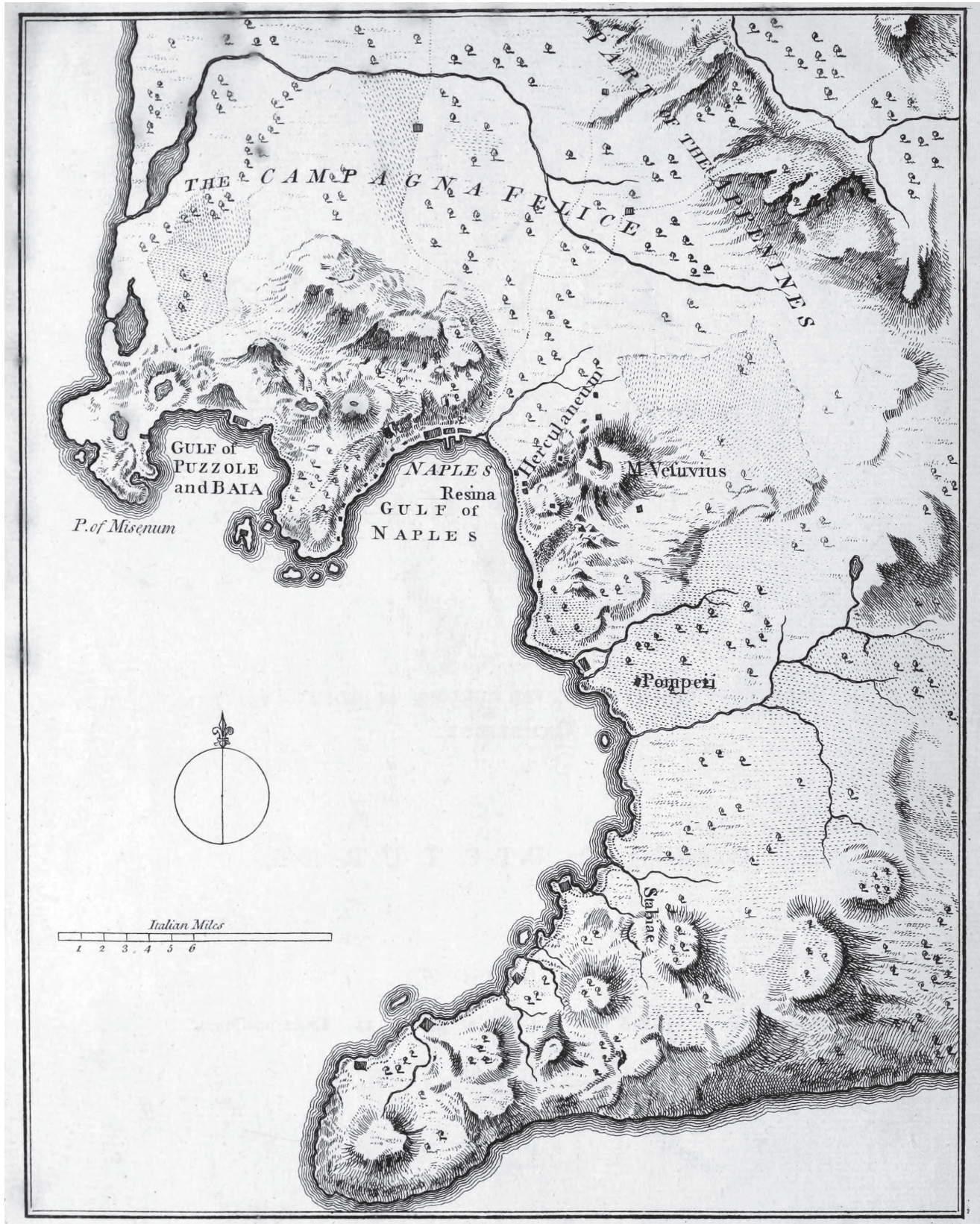

1. The Gulf of

Naples, The

Antiquities of

Herculaneum;

translated from

the Italian by

Thomas Marty

and John

Lettice... London:

Printed for S.

Leacroft, 1773

[Ottavio Antonio

Baiardi et al.,

Le Antichità di

Ercolano Esposte.

8 vols. Naples:

Regia Stamperia,

vol. 1, 1757].

Cederlöf: the fact of the astounding preservation of everyday objects and erotic wall paintings in Pompeii, but also the implementation of a policy of controlled viewing, although an added accent here will be on how such characteristics can be seen as directly affecting inherited attitudes to the Roman study journey. Something was putting at risk the idea that an artistic or scholarly attachment to the great pieces of antiquity was fuelled by feelings of admiration for a legacy that the passage of time and partial destruction had converted into a treasure trove of great masterworks. The Sergel journal has echoes of an excessive and dispersed outlook on antiquity, echoing other travellers' responses, for which the Vesuvian area became synonymous with a world that was of antiquity but not "classically" interred, ruined and reconstructed. 
The standard account of Sergel's decade-long Italian stint, bringing together evidence from the artist's letters and other evidence of visitors to his Roman studio, is Lars Olof Larsson's eloquently titled "Between Depression and Rebirth" ("Zwischen Depression und Neugeburt"), 3 although the activities of the sculptor during his stay in Rome and Paris have been the subject of invaluable contributions by Per Bjurström, Martin Myrone, Nancy L. Pressly, Jorgen Andersen and Anne-Marie Leander Touati. ${ }^{4}$ These authors have brought together evidence of a lively circle of artists that included the German Jakob Philipp Hackert (1737-1807), the Dane Nicolai Abilgaard (1743-1809), the Frenchman Julien de Parme (1736-1799), the Scot John Brown (17491787), and, the best-known of the group, the Swiss self-taught painter Henri Füssli. Indeed, Füssli's singular energy placed him in the vortex of a small society of artists whose focus on the more tormented but also irrational aspects of antiquity became fused with a love of profanity and libertine interest in sexual and morbid imagery. This tendency of the 1770 s has mostly received derivative labels, from the literary "Sturm und Drang" in earlier surveys, by way of the obvious references to proto-Romanticism, through to the label of "Neopaganism" to which I would subscribe. The latter term was coined by Andrei Pop in his recent book-length study Antiquity, Theatre, and the Painting of Henry Fuseli. ${ }^{5}$ Pop offers his neologism as a means of stressing that Füssli's work, although central to these developments, should be considered as a legacy shared in a community-not just a local community of artists, but an intellectual framework affecting perhaps first and foremost contemporary theatre, which from the 1760 os onward was deeply energized by attempts to recover the ancient plays and the forms of Greek tragedy. ${ }^{6}$ Thus, the taste for a dark stain of erotic and violent scenery, mostly fused in Füssli's drawings with readings from Homer, Shakespeare and Euripides, was neither exclusive to him nor without parallels in contemporary efforts to revive the plays of Shakespeare, Sophocles and Seneca. Moreover, they should be interpreted, Pop suggests, as evidence of a tectonic shift in the age-old relationship to antiquity. The "Neopagan" outlook heightened the sense of antiquity as a primitive expression of heroic vitality, sexual abandon and primal violence. Pop sees the boldest expression of such an attitude in the work of Johann Gottfried Herder (1744-1803), who traded the idea of a distinguished genealogy connecting modern enlightened culture to a Greco-Roman classical past with the "idea of equality of cultures in the plural, as civilizations sufficient in themselves". Both the focus on something too singular and too close to primitive culture to be imitable deeply destabilized the cultural practices of conventional classicism. It directly undermined the idea of an easy succession through the ages of "superior" cultural expressions from the time of Athens and Augustus to the great European nations of the modern world. Accordingly, Füssli and other "Neopagans" cast aside what had typically been celebrated as constitutive

3. LARsson, L.O., “Zwischen Depression und Neugeburt. J.T. Sergel und Thorvaldsen in Rome”, in SEIDEL, M. (ed.), L'Europa e l'arte italiana. Venice: Marsilio, 2000, pp. 517-530.

4. BJurström, p. (ed.), Johan Tobias Sergel - Kunst um 180o. Hamburg: Prestel Verlag, 1975; PressLy, N.L., The Fuseli Circle in Rome: Early Romantic Art of the 1770s. New Haven and London: Yale Center for British Art, 1979; MYRonE, M., Bodybuilding. British Historical Artists in London and Rome and the Remaking of the Heroic Ideal c. 1760-180o. New Haven and London: Yale University Press, 2008, pp. 275-294; Myrone, M., "Gigantic Talents in a Frivolous Age? Ambition and Desire in Rome in the 1770s", in Lederballe, T., Nicolai Abilgaard: Revolution Embodied. Copenhagen: Statens Museum for Kunst, 2009, pp. 164-77; LEAnder TouATI, A.-M., "How to Choose Ancient Models: the Example of Johan Tobias Sergel (1740 - 1802)", in Fejfer, J.; RAthje, A. (eds.), The Rediscovery of Antiquity: The Role of the Artist, Series Acta Hyperborea no. 10. Copenhagen: Museum Tusculanum Press, 2003, pp. 147-179, as well as the untranslated ANDERsEN, J., De Ar I Rom. Abilgaard Sergel Füssli. Copehagen: Christian Ejlers, 1989, and AnDERSEN, J. (ed.), Sergel. Stockholm: Nationalmuseum, 1990, which I have not been able to consult.

5. Pop, A., Antiquity, Theatre, and the Painting of Henry Fuseli. Oxford: Oxford University Press, 2012.

6. Ibidem, pp. 43-48. 
of greatness in Greco-Roman statuary and literature, and revelled instead in the singularity and eccentricity of a primitive vision that constituted its true "universality".

Hedonistic camaraderie comes to the fore in the aforementioned Neapolitan journey of October 1768, about a year and a half before Füssli's arrival in the city in May 1770, confirming that a "Neopagan" attitude bore no debt to the Swiss who later led the group. It is instructive to look at an account from Johann Christian von Mannlich (1741-1822) of the excursion to Naples, or rather the adventures that led a group of artist friends from Rome, which included Sergel and Mannlich along with the painters Dominique Lefevre (1737-1769), César Vanloo (17451821) and Christian Traugott Weinlich (1739-1799), to undertake the journey. ${ }^{8}$ Mannlich placed the group of friends inside the Villa Farnesina, on the shores of the Tiber, drawing after Raphael's Loggia di Pische. In a real-life doubling of the Loggia's loves of the gods, Mannlich wrote that he had attracted the gaze of a young Roman lady, who peeped on the friends from the neighbouring Palazzo Corsini. The young artists in their turn discovered her interest in Mannlich, and bullied him into a courtship involving ever bolder demonstrations of his masculinity. This stopped when the lady's father, the steward of Cardinal Corsini, discovered the affair. He demanded that the young German marry his daughter, swearing in the presence of the Director of the French Academy in Rome, Charles-Joseph Natoire, that failure to meet his demands would end in a bloody attempt on Mannlich's life. After this, Mannlich and his friends decided to leave Rome, scurrying from the father's demands and hoping that matters would calm down in Rome while they were away in Naples. Ulf Cedetlöf, in commenting on Sergel's journal, has underplayed Mannlich's story, choosing instead to validate Natoire's own diplomatic letter to the Surintendant des Bâtiments in Paris. Natoire knew it was not as a matter of course that French pensionnaires would be allowed to leave Rome and collect letters to see the antiquities in Naples. Natoire himself did so only on counted occasions, and his assistance to the Mannlich excursion was explained to Paris as an attempt to succour Lefevre, who had been plagued by a very poor state of health in the humid airs of Rome. ${ }^{9}$ Yet none of the elements of the Mannlich story seem to be out of place in mid to-late eighteenth-century Rome-not even the danger of an attempt on the artist's life, which calls to mind Winckelmann's murder just months before, or the later murder of the British sculptor John Deare in $1797 .^{10}$

Anne-Marie Leander Touati underlined that the intersection between hedonism and the properly artistic study of ancient models, already dimly present in Mannlich's adventure, was pervasive and informed Sergel's later development as an artist. In Mannlich's tale, it is the ease with which the artists stepped from an exercise in sexually tinted artistic piety (Raphael's Loggia di Psiche, after all, is about feasting gods) to one of romantic pursuit. To judge by the evidence of Sergel's journal given later in this article, the mentality that switched art for sex was well established. It is echoed, moreover, by Sergel's choice and assimilation of an antique model: the Drunken Satyr from the Villa of the Papyri, a work Sergel certainly saw among the royal exhibits in Naples (figure 2). A drawing that may have been made in Naples has a strong similarity with this raucous sculpture, and the parallels with Sergel's Drunken Faun, a small marble which the Swede finished in 1774, is again striking and would be difficult to explain by recourse to antiquities in the Roman collections (figure 3). But what should be underlined in the present context is how Sergel's succeeded in striking a note of deep sensuality and moral irreverence with his figure. To treat the ravings of drunken fauns and satyrs in bronze and marble is to deny sculpture

7. On "Neopaganism" see Pop, A., Antiquity..., pp. 43-54.

8. For Mannlich's recollections, see STROLLREITHER, E. (ed.), Ein deutscher Maler und Hofmann: Lebenserinnerungen des Johann Christian v. Mannlich 1741-1822. Berlin: E.L. Mittler, 1910, pp. $123 \mathrm{ff}$.

9. For the problem of "bad airs" and influenza affecting artists in Rome, see WRIGLEY, R., Roman Fever. Influence, Infection and the Image of Rome, 1700-1870. New Haven-London: Yale University Press, 2013, especially, pp. 21-43.

10. On Deare's Roman career and the versions of the story of his murder, see FogELMAN, P.; Fusco, P.; STOCK, S., "John Deare (1759-1798): A British Neo-Classical Sculptor in Rome", Sculpture Journal 4, 2000, pp. 85-126 (91). 
2. Drunken Satyr from the Villa of the Papyri,

1st century AD, bronze. Museo Archeologico Nazionale di Napoli, Naples.

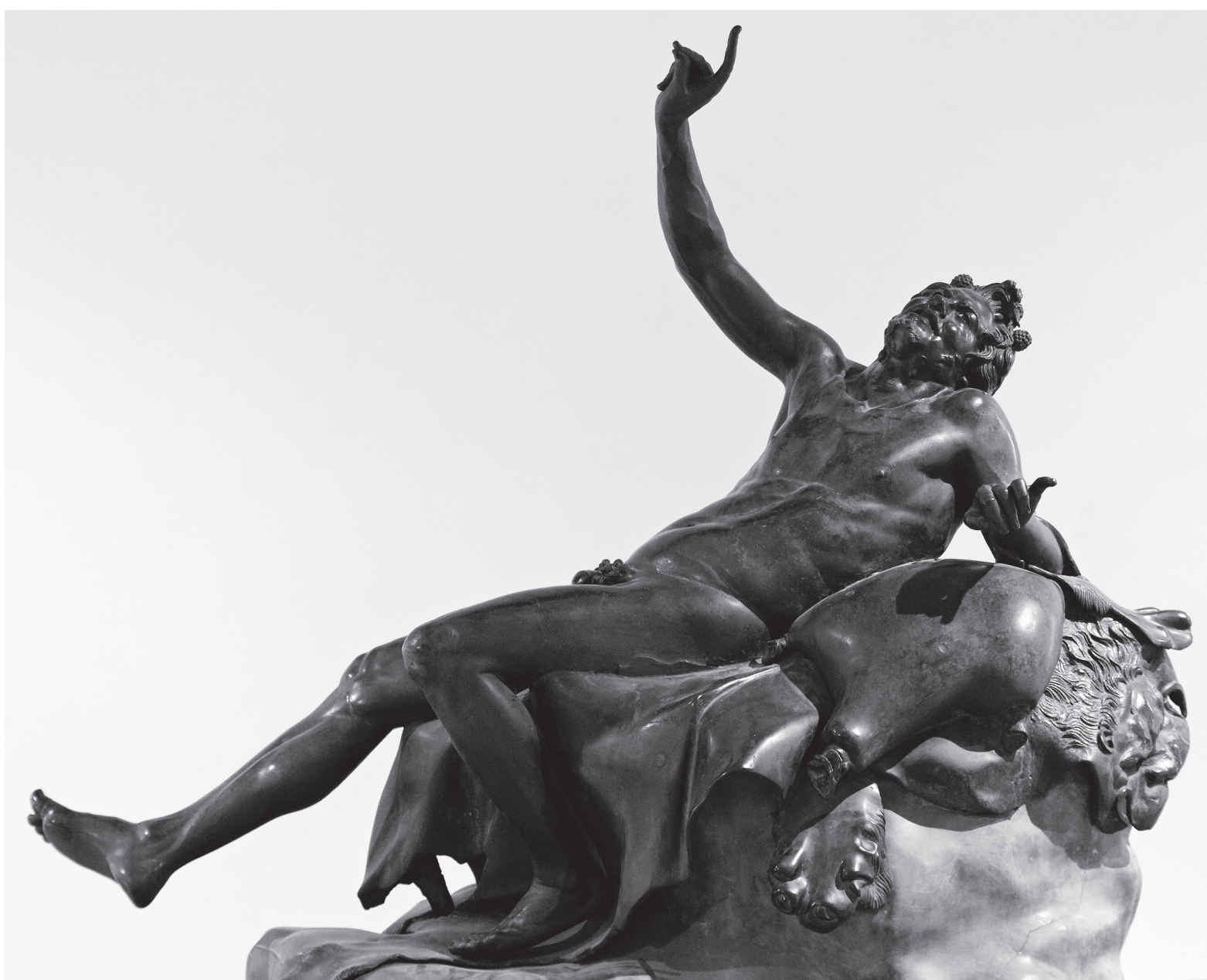

the exemplary or representative function that still belonged to the courtly and academic aspirations of the time. It suffices to call to mind Etienne-Maurice Falconet's famous dictum, in his Réflexions sur la sculpture from 1759 , that antiquity was to be admired for its cult of great men, but derided whenever, as in images of Venus, it united sex with cult."

Sergel's Faun moves his body sideways and glares up in a not altogether innocent invitation. Yet the figure shuns the anecdotic animation of the Villa of the Papyri bronze, which John Flaxman described in 1788 as "snapping the fingers of his right hand". ${ }^{12}$ Sergel's Faun has not the energy to sit up or even to gesture. But Sergel also imbued his figure with an almost baroque breathing vigour: thoroughly toned in the torso and solidly shaped in the leg area, suggesting a life of solid physical strain, its sideways turn has something predatory about it. This, then, was Sergel's response to one of the great discoveries of Charles VII's Neapolitan excavations, a work that was cast and shipped as early as 1766 to the collection of Madrid's Real Academia de Bellas Artes de San Fernando, where the cast was recently put on public display again (figure 4). In the

11. On Falconet's passage and the debate over natural drives in late Enlightenment discussions of ancient statuary, see MacsotaY, T., "Baron d'Hancarville's Recherches on the evolution of sculpture: submerged emblems and the collective self”, in VAN ECK, C. (ed.), From Idols to Museum Pieces. The Nature of Sculpture, its Historiography and Exhibition History $1640-1880$. Paris, École du Louvre - De Gruyter Verlag 2017, pp. 127-144.

12. Wright, A.E., "Flaxman's Taste for the Antique: Some Themes in the Early Months of Flaxman's Grand Tour", in Brigstocke, H.; MARCHAND, E.;WRIGHT, A.E., John Flaxman and William Young Ottley in Italy. Wakefield: Walpole Society, 72, 2010, pp. 47-60 and the transcription of the UCL Notebook on pp. 187-218 (191). 


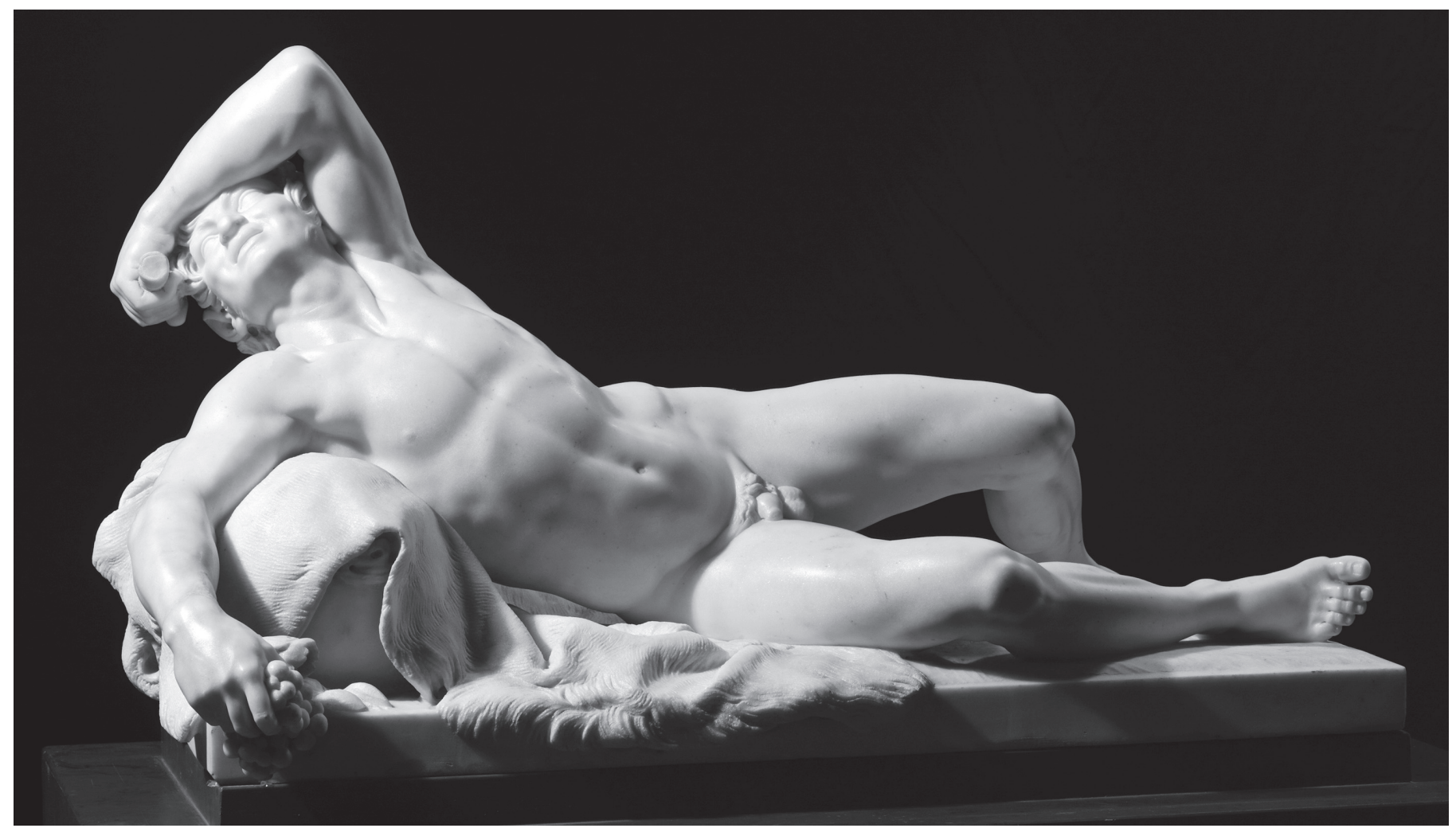

Swede's hands, the bronze from Herculaneum becomes a testimony of the unceremonious spirit that had taken a hold of young artists' attitudes by the late 176os. "Neopagan", to return to the label mentioned earlier, is an adequate name for such attitudes. As in Mannlich's plot of love of art, courtship and conquest, Sergel's reclining figures, which also include his spectacular, tragic Othryades (figure 5), attest to Sergel's affinity with Hellenist and Roman naturalist sculpture in figures heavily invested with an ideal of virile physicality.

The "libertine" breeze that blew through artists' communities around the turn of the 1770 s has again attracted important interpreters, like Nancy Pressly and Joan Sureda-the latter with a thorough collaborative study on Francisco de Goya's sojourn in Rome in 1769-71. It must, however, not be read purely in terms of a dismissal of "tradition"." The principal gesture was not one of rupture with regard to a confining canon. Both Mannlich's Loggia di Pische and Sergel's Neapolitan antiquities belong to a broader spectrum of copy models, just as was the case with French academic precedents, particularly those that flourished under inspired directors of the French Academy on the Via del Corso, which included Nicolas Vleughels in the 1730 s and Charles-Joseph Natoire in the 1750 s and 1760 s. ${ }^{14}$ What began to put these academic practices under strain was not an upheaval in the choice of traditionally admired artists and antiquities, but rather the amalgamation of a choice of certain works with visions of violence and virile (and sometimes also womanly) presence and power. It seems as if a personal attitude to life found an echo in the venality of the Faun and Othryades, an unusual sculptural achievement that was not mimicked by the likes of Canova and Thorvaldsen. The question that must be asked next is: did the Neapolitan archaeological visit constitute a site of such libertine and pagan "emancipations"?

13. Pressly, N.L., The Fuseli Circle..., and Sureda, J. (coord.), Goya e Italia, exh. cat., 1 June - 15 September 2008, Museo de Zaragoza, Zaragoza, 2 vols. Madrid: Fundación Goya en Aragón -Turner, 2008.

14. Macsotay, T., The Profession of Sculpture in the Paris Académie. Oxford: Oxford University Studies in the Enlightenment, 2014, pp. 161-168.

3. Johan Tobias Sergel Drunken Faun, 1774, marble, $47 \times 86 \mathrm{~cm}$. Finnish National Gallery, Helsinki. 
4. Drunken Satyr from the Villa of the Papyri, before 1766 , plaster. Real Academia de Bellas Artes de San Fernando, Madrid.

5. Johan Tobias Sergel

Othryades, after 1779, plaster, $63 \times 61 \mathrm{~cm}$. Göteborgs Konstmuseum, Gothenburg.
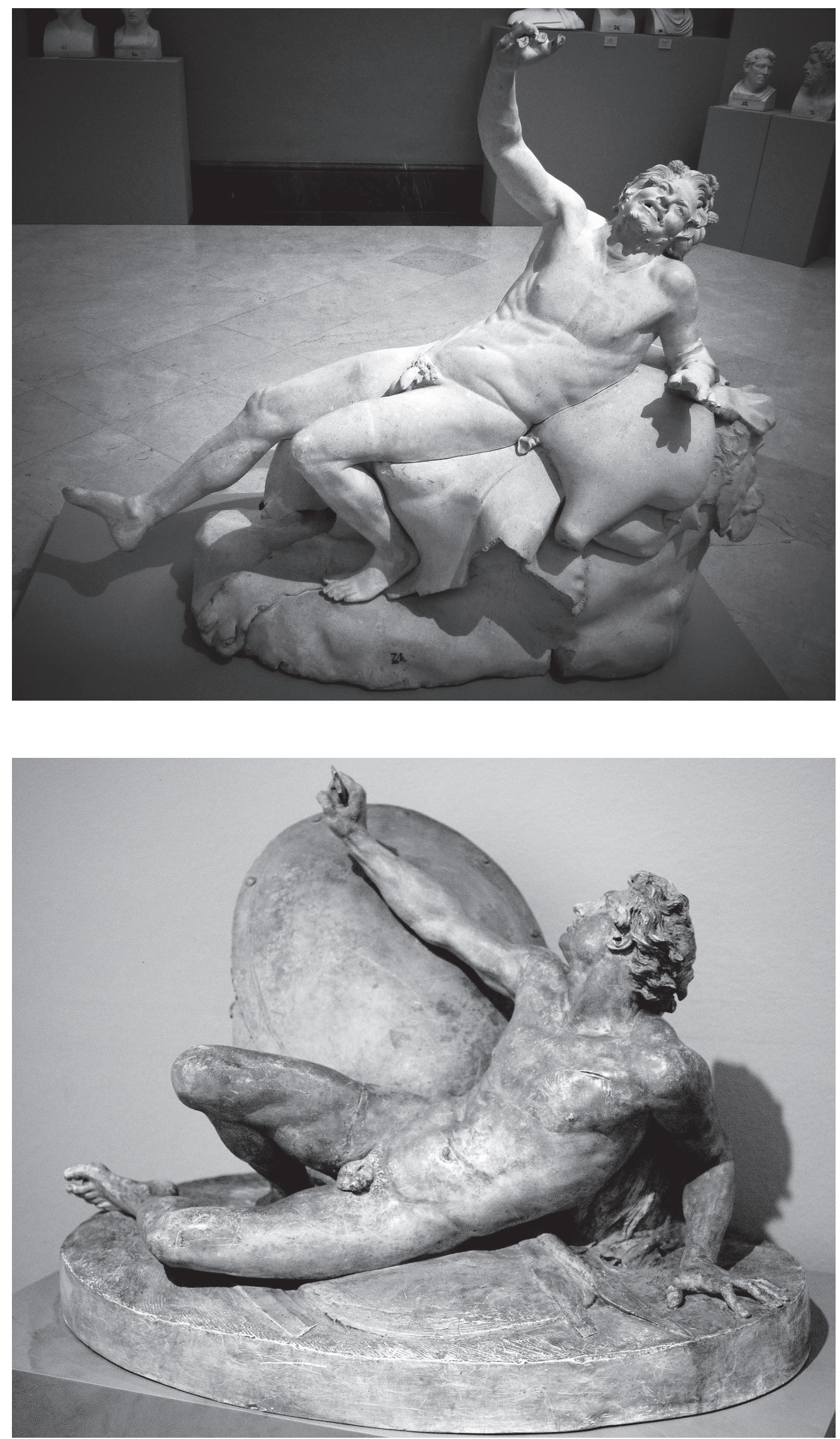

120 - Articles 


\section{Differentiating NAPLES From Rome}

It has often been remarked that the eighteenth-century reception of artworks recovered from the lava of the Vesuvius has been a history of deceptions: travellers confronted with collections of the wall paintings that were moved by the Neapolitan King Charles VII to the Royal Cabinet in Portici tended to be disappointed. However, a narrowly framed focus on pictorial taste and criticism has meant that the materiality of the Neapolitan objects and sites has been examined less often. ${ }^{15}$ The cities that lay buried underneath the pumice and lava from the Vesuvian eruption in $79 \mathrm{AD}$ were being purchased piecemeal, and as excavation and backfilling advanced their treasures were taken to a special gallery accessible only upon special royal concession. The Herculanense Museum, installed in two separate galleries in the adjacent Palazzo Caramanico and Palazzo Reale, would soon be known simply as the Portici Museum. It was an exciting place to visit, for it teemed with ancient painting of which so few examples survived elsewhere.

These treasures were being published in the form of scholarly descriptions and reproductive engravings, but only at slow pace: Le Antichità di Ercolano Esposte, the Accademia Ercolanese's official report on excavated treasures, was published between 1757 and $1792 .{ }^{16} \mathrm{Le}$ Antichità came in for a good measure of criticism for its tendency to mask the original wall paintings' faulty perspective or embellish contours, but also for its slow publication history and pedantic approach to distribution, which depended on subscription of limited print runs. In 1751, when a team of scholars and draughtsmen were already at work on Le Antichità, the French engraver and theorist Charles-Nicolas Cochin was allowed to view the collections and see the draughtsmen at work. He soon noticed the effort to "improve" on the originals and gave notoriety to this in his Observations sur les antiquités d'Herculaneum, which he later reissued in an English translation.

Cochin's visit to Naples had been an important diplomatic event, involving not just two young architects, Jacques-Germain Soufflot and Jerôme-Charles Bellicard, who left an elaborate notebook of his visit, but also l'Abbé le Blanc, historiographer to the French king. In his earliest published account, the Lettre sur les peintures d'Herculanum from 1751, Cochin characterized the Neapolitan management of the paintings, and the official engravings workshop, as possessive and opaque, wishing that a friendlier politics would ensue, so that

the learned, the antiquarians, and above all the skilled draughtsmen, would be able to enlighten the public by their studies, or do, in one word, on those precious monuments that which they have been always at liberty to do in every country, even in those where the fact of Religion and barbarism have made it difficult. ${ }^{17}$

The royal benefactor, King Charles VII (who vacated the throne in 1759 to be crowned Emperor Charles III of Spain), was thus cast in the role of a royal censor, standing in the way of

15. See, for studies on antiquarianism and the focus on vase painting and the wall paintings, ScHNAPP, A., "Antiquarian Studies in Naples at the End of the Eighteenth Century. From Comparative Archaeology to Comparative Religion", in IMBRUglia, G., Naples in the Eighteenth Century. Cambridge: Cambridge University Press, 2007, pp. 154-166, and RAMAGE, N., "Flying Maenads and Cupids: Pompeii, Herculaneum, and Eighteenth-Century Decorative Arts", in MaTTUSCH C.C. (ed.), Rediscovering the Ancient World on the Bay of Naples, 1710-189o, Studies in the History of Art 79. Washington: National Gallery of Art, 2013, pp. 161-176.

16. On the process of excavation and production of engravings for the Antichità di Ercolaneo Esposte, see PARsLow, C.C., Rediscovering Antiquity: Karl Weber and the Excavation of Herculaneum, Pompeii and Stabiae. Cambridge: Cambridge University Press, 1998, and RAmage, N., "Flying Maenads..."

17. “Les Sçavans, les Antiquaires, ou surtout les bons Dessinateurs, pourront alors éclairer le public par leurs études, ou faire, en un mot, sur ces précieux monuments, ce qu'il leur a toujours été libre de faire dans tous les païs, même dans ceux que la différence de Religion \& la barbarie ont rendu le moins praticables". CocHIN, C.N., Lettre sur les peintures d'Herculanum. [S.1.]:[s.n.] 1751, pp. 9-10. 
the penetrating and enlightened gaze of informed viewers and "skilled draughtsmen" and preventing them from giving direct scrutiny to the objects. ${ }^{18}$

To be sure, Naples was attracting a sort of painter that had little interest in studying the antique: as one of the principal ports of call for wealthy travellers and gentry on the Grand Tour, there was a lively trade in panoramic views of the Bay of Naples, Mount Vesuvius and the adjacent countryside. ${ }^{19}$ Foreign painters and sculptors who visited Naples from a more stationary address in Rome often had to bypass permissions and obstacles put up by their beneficiaries, and in some cases the French Academy in Rome and other diplomatic missions would need to arm them with appropriate letters. Artists also gained access to Naples' inaccessible antiquities by learning from the drawings their friends made. As Marianne Roland-Michel demonstrated, many who did travel to Naples and other destinations off the principal route of access to Rome made counterproofs of drawings that their peers in Rome would in their turn study or copy. ${ }^{20}$

Yet the new museum at Portici remained problematic. Winckelmann was initially denied a visa when he tried to visit Naples in 1756, and needed to call in help from the court of Dresden to be finally admitted into Portici in $1758 .^{21}$ An expression Cochin used is that of a "frightening captivity" ${ }^{22}$ in which the Neapolitan crown held its archaeological remains, hinting perhaps at a link to the cult of relics and to the veiling nature of Catholic and idolatrous objects that has enormous potential in considering the impact of the Vesuvian sites. Cochin's dismissal of the Bourbon archaeological apparatus would become recognizable to later travellers: Goethe's visit on 18 March, 1787, is a case in point. Goethe had called Portici "the alpha and omega of antiquities collections", but he complained about the restrictive supervision to which visitors were subjected, prohibiting them from keeping any kind of written notes or attempting drawings of any sort. A pushy guide forced the visitors to pass from room to room, giving them just enough time to "snatch away", as Goethe writes, "delight and learning". In combination with the slow progress of the reproductive venture, there were attempts at image smuggling through quick records: this happened in 1755 when a sculptor by name of Laurent Guiard, "smuggled" in his memory, or perhaps in some notes, the Balbus. Guiard modelled his "copy" with a fiat from Natoire and exhibited it at the French Academy in Rome, causing quite a diplomatic stir with the Neapolitan court. ${ }^{23}$

The typical joint working sessions that Mannlich described in the Farnesina, where groups of artists sat together to copy, were harder to "implement" in Naples' principal repository of antiquities than in the churches or collections of Rome. In part, this was because the painting could barely pass the test of a discriminating audience. Writing an opinion echoed for much of the remaining century, Cochin wrote in 1751 that "by any account and in all times, the paintings of Herculaneum have never been comparable to those of the capital villages in which the fine arts reigned. ${ }^{\prime 24}$ On top of this, the jealous supervision at Portici stood in the way of patient prac-

18. On Cochin's expedition and Bellicard's contemporary notebook, see GoRDON, A.R., “Jérôme-Charles Bellicard's Italian Notebook of 1750-1751: The Discoveries of Herculanum and Observations on Ancient and Modern Architecture", The Metropolitan Museum Journal, 25, 1990, pp. 49-142, and MicheL, C. (ed.), Le Voyage d'Italie de Charles-Nicolas Cochin. Rome: École française de Rome, 1991. The most influential account, first published in 1755, was Cochin, C.N. ; BELLICARD, J.-C., Observations sur les Antiquités d'Herculanum avec quelques réflexions sur la peinture \& la sculpture des anciens; \& une courte description de plusieurs antiquités des environs de Naples. Paris: Jombert, 1755.

19. For a reconstruction of lives of these vedute painters, see the exhibition catalogue In the Shadow of Vesuvius. Views of Naples from Baroque to Romanticism 1631-183o. London: Accademia Italiana delle Arti e delle Arti Applicate, 1990.

20. See Roland-Michel, M., "Dessiner à Rome au temps de Pajou”, in Scherf, G. (ed.), Augustin Pajou et ses contemporains. Actes du colloque, Musée du Louvre, 7-8 November 1997. Paris: Ecole du Louvre, 1998, pp. $287-98$.

21. Harris, J., Pompeii Awakened: A Story of Rediscovery. New York: I.B. Tauris, 2007, p. 59.

22. "Je crois vous avoir déjà prévenu, mais il est à présumer que l’on ne tiendra plus ces trésors de l'antiquité dans l'effroyable captivité où il sont à présent." Cochin, C.N., Lettre sur les peintures..., p. 9.

23. For the anecdote, see Macsotay, T., The Profession..., p. 203-204.

24. “Dans tous les cas et dans tous les tems, les Peintures d'Herculanum n'ont jamais été comparables à celles des Villes capitales où regnoient les Beaux Arts". CochIN, C.N., Lettre sur les peintures..., p. 7. 
tices whereby copy drawings could be produced and stored in albums. In its stead, Sergel and his friends needed to store images in their memories or remember stories. Something similar also applied in places like Pompeii to the excavated houses, streets and graves; what seems to have struck many there was not a clear alignment of admirable masterworks, but rather a laden mood created by a landscape of uncovered houses, a temple, and some graves. Herculaneum was a hole cut into the deep group: a theatre could be seen only by torchlight.

As C.C. Mattusch has underlined, some of the pieces best valued by eighteenth-century visitors to Portici were sculptures from the Villa of the Papyri, which include the above-mentioned Drunken Faun, so central to Sergel's own reception of antique models. ${ }^{25}$ The special figure that the Vesuvian area struck in an artistic and archaeological imaginary of the Enlightened visitor was indeed closely allied with the sense that the visitor passed a private threshold, discovering the intimate world of the recovered houses. Such imaginative recreations were amplified by the profound knowledge about the drama of Pompeii's destruction mediated by the surviving eyewitness account of Pliny the Younger's much read letters on the catastrophe.

Nowhere is this better captured than in speculation over the few skeletons that were found in the terrain. ${ }^{26}$ In his letter to the count Heinrich von Brühl from 1764, Winckelmann explained the established theory on the process of asphyxiation, ignition and slow encasing to which a small group of original inhabitants had been subjected. He remarked that the slowness was attested by the fact that Pompeii had no human remains, but that excavations in nearby Gragnano and Stabia had yielded a group of three women who had perished on an escape route: two mistresses wearing bracelets and a slave who was leaning on an object that disintegrated when it was touched-Winckelmann thought it had been a small wooden box. ${ }^{27}$ Pliny's account concurred in this initial reconstruction - later contradicted by additional finding of bodies-of an initial layering of fine ashes, pumice and blackened stones, which would have asphyxiated, then gently encased the bodies (figure 6).

Artists' responses to these fossil-like casings include, in 1788, notes left by John Flaxman in one of his journals, currently preserved at the UCL in London. In Portici, he confronted

the upper part of the front of the body with the breasts of a woman[.] one of the unhappy victims on the destruction of Pompeia, the mould is about the colour \& consistence of rotten stone, the impression is exact[.] the drapery remains in folds[.] it is fine open linen [sic], \& the folds in fineness exactly resemble that on the antique statues. ${ }^{28}$

When in Pompeii, Sergel, Flaxman and other travellers were paraded to see the few recovered skeletons and moulds. Like the skeleton Winckelmann had identified as a reclining slave, they saw a woman who reclined and languished. In one instance, we find mention in the Recherches sur l' origine, l' esprit et le progrès des arts de la Grèce from 1785 of a "skeleton of a woman who had not been able to leave the place where she was found".29 The Recherches was authored

25. On the Drunk Faun and other sculpture found at the Villa dei Papiri, see Matrusch, CC., The Villa dei Papiri at Herculaneum. Life and Afterlife of a Sculpture Collection. Los Angeles: Getty Institute, 2005.

26. On the long tradition of casting the Vesuvian visit as an encounter with death, see HaLEs, S., "City of the Dead", in Hales, S.; Paul, J. (eds.), Pompeii in the Public Imagination from its Rediscovery to Today. Oxford: Oxford University Press, pp. 153-70.

27. “On a lieu de conjecturer par le petit nombre de corps morts, que les habitans eurent le temps de prendre la fuite; car on n'a trouvé aucun squélette ni à Portici, ni à Resina, ni à Pompeii ; ce n'est qu’à Gragnano ou à Stabia, qu'on a découvert trois corps de femmes, dont l'une, qui étoit sans doute la servante des deux autres, portoit vraisemblablement une petite cassette de bois qui s'est trouvée placée à ses côtés, ou qui, lorsqu'on a voulu y toucher, est tombée en poussière." WINCKELMANN, J.J., Lettre de M. l'abbé Winckelmann, antiquaire de sa Sainteté, a monsieur le comte de Brühl, chambellan du roi de Pologne sur les découvertes d'Herculanum. Traduit de l'allemand. Dresden: Tilliard, 1764, p. 13.

28. Wright, A.E., “Flaxman's Taste...", p. 191.

29. D'Hancarville, Baron (Pierre-François Hugues), Recherches sur l'origine, l'esprit et le progrès des arts de la Grèce, sur leur connection avec les arts et la religion des plus anciens peuples connus. 2 vols. London: B. Appleyard, 1785, vol. 2, p. 13. 
6. Resin casts of two women unearthed in the garden of the house of Cryptoporticus at Pompeii. On display in several locations.

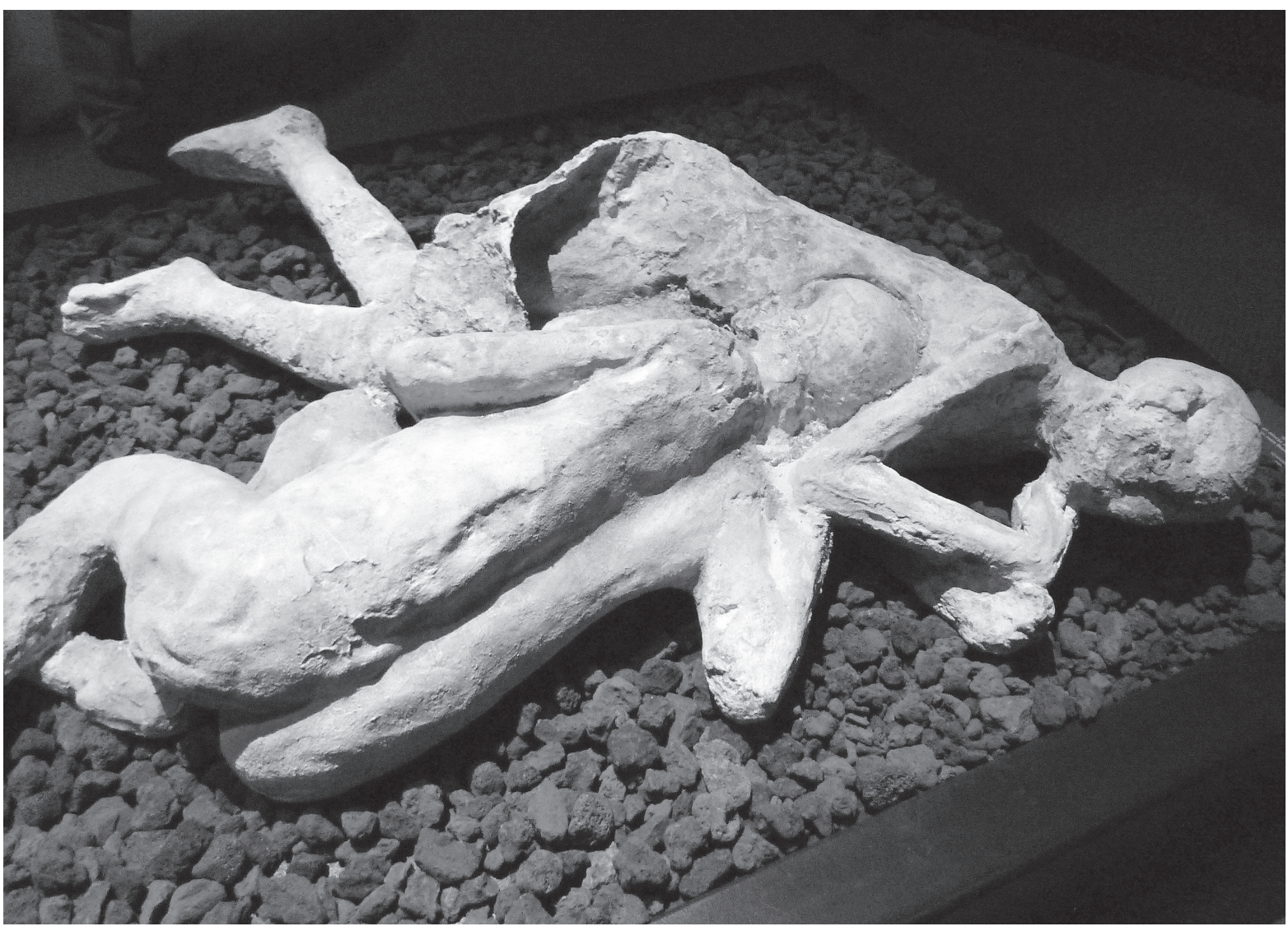

by Pierre-François Hugues d'Hancarville, an acquaintance of Flaxman's, who divided his time between the famous luxurious edition of William Hamilton's "Etruscan" vase collection-again a collection that was kept in Naples - and stints as an anonymous pornographer. He was a fellow of the "Neopagan" network as defined by Andrei Pop, which in part explains that he, much against the prevailing thesis, thought the ashes had entrapped some people to their deaths. This woman's skeleton was found, or at least displayed, in the Sarno Baths, the earliest bath site recovered in Pompeii, and integrated into the guided visit, one can assume, for dramatic effect. Dramatic too was d'Hancarville's interest in the delicacy of the figure's pose and pale bones:

one of her elbows leaned on the rim of a very large vase, next to which she sat; her attitude marked by the most profound despondency: all the bones of this skeleton had remained in place, and they were of the most perfect whiteness, as in the most perfect conservation. ${ }^{30}$

It is hard to read the description and not be reminded, somehow of Sergel's Faun or Othryades. As for Sergel, he too was able to enter the Sarno Baths site and see the same figure, which he took to be a man, when he visited in 1768 . The Swede was convinced that the ash had covered the figure "without his being able to save himself", and indeed reported an ominous sign of subterranean effusion, perhaps of sulfur: "an unbearable offensive air which prevents anyone from long remaining there". ${ }^{\prime 1}$

30. Ibidem, vol. 2, p. 13.

31. Leander Touati, A.-M.; CederlöF, U., “Observations on the museums...”, pp. 157-158. 


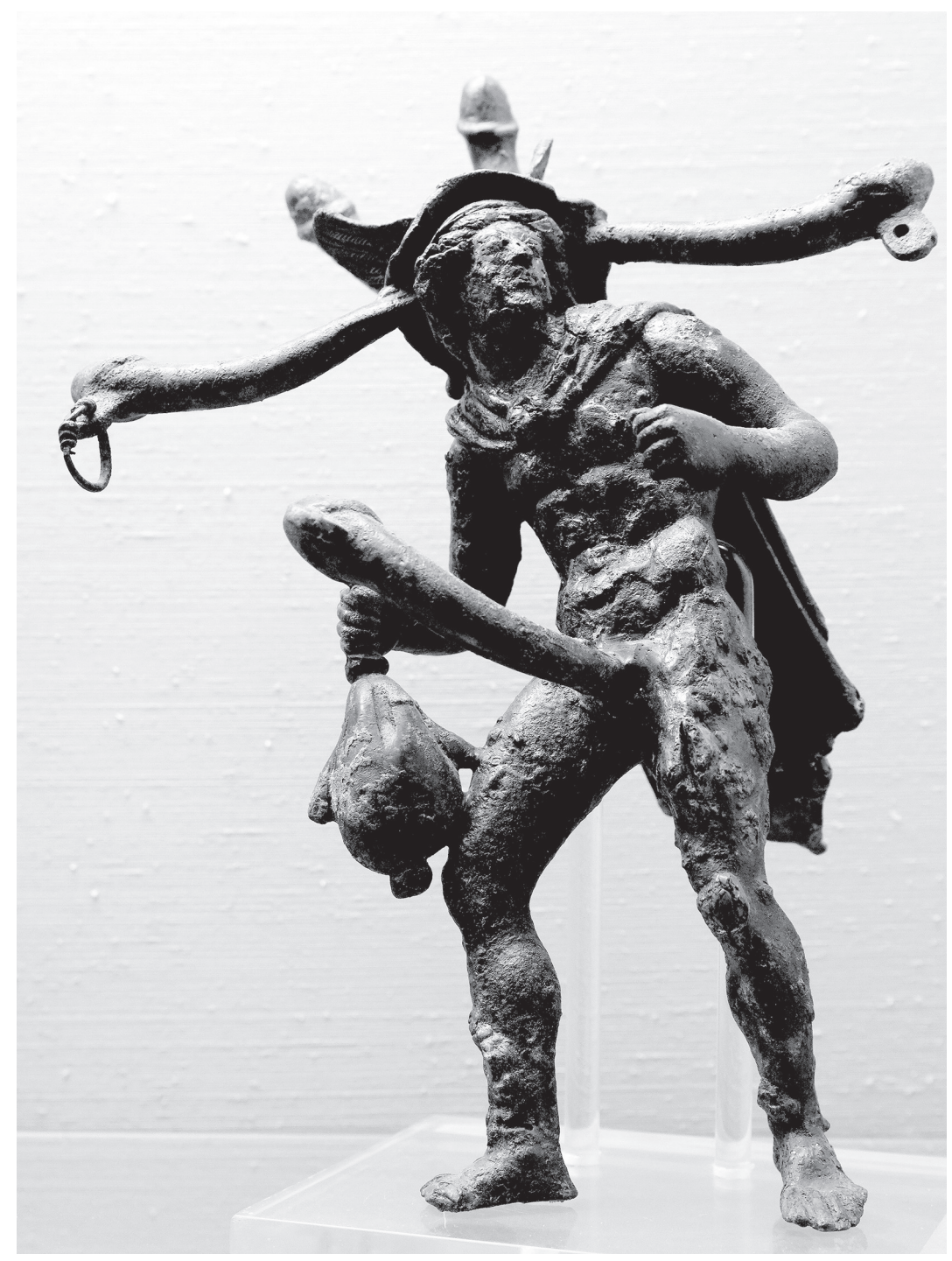

7. Tintinnabulum (bell-bearer), with a figure of Mercury bearing a sack of coins and a halo of phalli on his head, ist century $\mathrm{AB}$, bronze. Gabinetto Segreto, Museo Archeologico Nazionale di Napoli, Naples.

But human remains and the constant reminders of death were not the only haunting element in the sites. The priapic or grotesque inflection of the three-dimensional figure when incorporated into a lamp or tripod, amulet or jug, gave Sergel a particular thrill. In one of the rooms of the museum, a lamp formed in the shape of "a satyr whose privy member is erect" drew the sculptor's attention..$^{32}$ Sergel was given to understand by his guide that it was in fact a milk pitcher, so that when milk was dispensed, it poured out in suggestion of semen. Sergel took it for fact that the artefact "also served for carnal stimulation". ${ }^{33}$ Pompeii gave the viewer Hellenist and Roman naturalist observation in the Villa of the Papyri's animal sculpture and satyrs, ideal beauty in the running athletes, but also erotica and Piranesi-like eccentricity in amulets, home appliances and utensils. A lot of this blended the anthropomorphic with the ornamental, sculpture with furniture (figure 7). The erotica, which invaded some of the wall paintings, was prominent in objects meant to be handled, giving the gaping Nubian mouths and faun's furs and priapic furniture an explicitly epicurean thrill to the owner.

32. Ibidem, p. 157.

33. Idem. 
The wax-museum quality of some of these objects of course amplifies the sense of what Cochin could have been aiming at, when he wrote of a "frightful captivity". The primacy of touch, exacerbated by the inclusion of moulds of victims' bodies or the ghostly return of skeletons in the open field of the excavated Pompeii, must have drawn associations with primitive shrines or the cult of relics in precious containers typical of the Catholic sanctuary. In that sense, royal benefactors and visitors alike navigated a space fraught with immediacy, an immediacy that sat oddly with the Bourbonic sense of its ownership of the objects and monopoly on reproductive images made after them. But it was also at odds with the spirit of Enlightened inspection favoured by Cochin or Winckelmann: the sense that the beholder had a place to occupy which was fixed, distinct and opposite from the antiquarian objects, neatly organized to appear as containers of encyclopaedic knowledge unfolding before their very eyes. There was a visceral and emotional element to Pompeii that visitors needed to develop a taste for, and which slipped through the cracks of a system of immaterial images that Pascal Griener has identified as the main object of an Enlightenment-era knowledge of art. ${ }^{34}$

\section{From Admiration to Shock}

One can see Sergel's visit to Naples as a meeting of worlds: a libertine spirit which had been appearing among artists' circles in Rome played out its fantasies on the Portici and the fields of Pompeii. It begs the question of a changed attitude to antiquity along lines of a "Neopagan" interest in antiquity as a vital, but also irrational and darkened culture. And it is likely we should take even more of Naples into consideration here. One of the memorable sights for many who visited Naples in the 1770 s and 1780 s as guests of the famous collector of antiquities and volcanologist William Hamilton was the night-time entertainment provided by his then wife, Emma Hart, known as Lady Hamilton. Andrei Pop again has argued that Hart's enactment of poses from figures seen in antique vases or inspired by ancient characters was meant to convey the experience of a dream, much like Füssli's incantatory image of a woman and her reactions to monstrous presences in his painting of a Nightmare..$^{35}$ The fact that many who would see Hart's attitudes at night had visited Portici or Pompeii in previous days has not been given the attention it deserves. Naples forwarded a more dynamic way of imagining antiquity.

Between 22 July and 20 August of 1779, it was Jacques Louis-David who descended upon Naples, in all likelihood armed with letters from the French Academy. An oral tradition, recorded by a number of early nineteenth-century biographies, had it that David travelled to Naples to see the antiquities, and that he too was accompanied, according to some, by a sculptor by the name of Suzanne, while others claim it was Quatremère de Quincy, the sculptor, architect and soon-to-be theorist. In a recollection from 1845, Auguste Jal offers a version which fails to detail what was to be seen in and around Naples. It submits, however, that David had long been struggling in Rome to improve his ability on the best masters of antiquity and the Renaissance, and that when stepping on Vesuvian soil, David experienced a "sudden revelation" (illumination soudaine), a real turning point in his artistic path:

34. For the creation of an episteme of the immaterial image, see above all Griener, P., La République de l'Oeuil. Expérience de l'art au siècle des Lumières. Paris: Odile Jacob, 2010.

35. Pop, A., "Sympathetic Spectators: Henry Fuseli's Nightmare and Emma Hamilton's Attitudes", Art History, 34.5, November, 2011, pp. 935-957. 


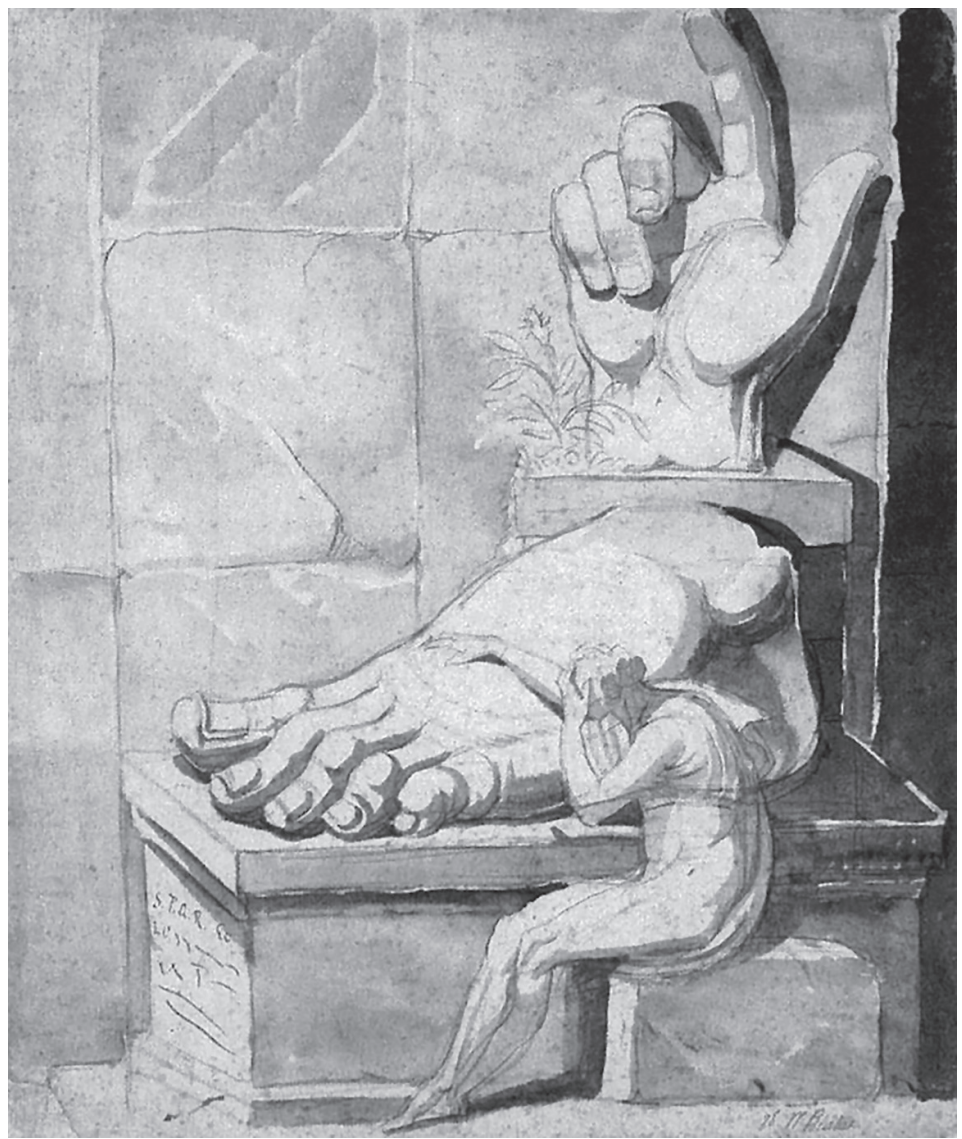

8. Henry Füssli The Artist's Despair Before the Grandeur of Ancient Ruins, 1778-1780, red chalk on sepia wash, $42 \times 36 \mathrm{~cm}$. Kunsthaus Zürich, Zurich.

It seemed to me that I had just undergone an operation of Cataracts, he said. I understood that I could not improve my manner (manière) of which the foundation was wrong, and that I needed to break away from all that I believed at first to have been beautiful and true. ${ }^{36}$

The cataract operation inaugurated for David the practice that proceeded in analogy to the famous Molyneux operation, returning sight to a man who had never been able to see. David, like Molyneux, would become a witness to the process of his own entry into the realm of visual experience. For what his eyes conveyed to him he had no anterior referent. ${ }^{37} \mathrm{Jal}$ was more able to capture the wording of a convulsed subjectivity than to specify what sights, if any, could have contrived such a change. But the sudden revelation, like that of Saint Paul, can be deciphered as a shock, a moment of deep instability after a long immersion in "misguided" practices of studying the antique. In that sense, it is a worthy companion to Füssli's image of an ailing artist at the foot of two fragments of the colossal statue of Constantine, his famous The Artist's Despair Before the Grandeur of Ancient Ruins (figure 8), made between 1778-1780-in another exact overlap with David's excursion to Naples. To be sure, the mood of Füssli's drawing has become one of the favourite hobby horses of art history writing on the Roman episode. Young artists are imagined as helpless apprentices, reduced by the masterpieces of antiquity to a devastating filial devotion

36. "Il me sembla qu'on venait de me faire l'opération de la cataracte, disait-il. Je compris que je ne pouvais pas améliorer ma manière dont le principe était faux, et qu'il falloit divorcer avec tout ce que j'avais cru d'abord être le beau et le vrai." JAL, A., "Notes sur Louis David, peintre d'histoire", Revue étrangère de de la littérature, des science et des arts, 55.15, 1845, pp. 623-700 (624).

37. On Molyneux and the mid-century debate on aesthetic perception, see LICHTENSTEIN, J., La Tache aveugle: essai sur les relations de la peinture et de la sculpture à l'âge moderne. Paris: Gallimard, 2003, pp. 68-93. 
mixed with self-effacement. Indeed, initial crises and depressive lapses, resolved by meteoric or delusional enthusiasm and fever for the antique, are phenomena that seem to have affected a number of Rome's visitors. In fact, Sergel, along with Bertel Thorvaldsen and Théodore Géricault, are documented examples. ${ }^{38}$ But art history has not warmed much to the sense of an entitled, unhinged, sexualized release before antiquity. And Füssli and Sergel's work shows examples that provide a more accurate context for The Artist's Despair.

Support for understanding these processes, and Naples' role therein, is available in the form of experiences by ordinary travellers from fashionable Grand Tour literature. ${ }^{39}$ A single example can be included here: Lewis Engelbach, writer of an amusing and evocative collection of fictional letters, recounts a tour through Naples and the surrounding countryside. In a letter on a visit to Pompeii Engelbach eloquently described a sense of time coming to a halt as a result of his sudden trespass from a modern cultivated field to the ancient cityscape, made in just a few human steps. The passage is highly graphic on the psychic power of the Vesuvian area, and at the same time shows a visitor who responds to it as a man of sensibility:

It is from a corn-field you descend into the excavated upper end of the High-street of this town. An awful sensation of melancholy seized upon my mind when I beheld these sad remains of former opulence and comfort. In viewing the remnants of remote ages, we are generally capable of tracing the period of their duration from exterior marks left upon them by the hand of time. But here, I confess, my ideas of time were so strangely assailed and bewildered, that, were I to repeat all the whimsical doubts which on this occasion found their way into my brain, my possession of the latter might, I truly fear, be disputed. What, said I, is this string of events, this something, which history intercalates between the catastrophe and discovery? A point in the infinite series of eternity; the passing of which we contrive to ascertain by the apparent rotation of the sun, or of some heavenly body or other within our observation. ${ }^{40}$

Engelbach, who puts "time" in capital letters, dwells on the minimal effort that is required to pass the threshold into a place that existed two thousand years ago and got sealed into the landscape. Time has gone missing between $79 \mathrm{AD}$ and now. We lose our footing in it: distance somewhere got lost. Along with Sergel's notes, and those of Flaxman and d'Hancarville, a case can be made for the Neapolitan settings as representing something more alive than a simple amalgamation of objects recovered from the soil. It seemed to have the capacity to turn into a theatre where visitors felt transported, where relic-like remains and uncanny foodstuffs and lamps gave a sense of visceral immediacy to some of the sights offered to visitors. Indeed, the objects-and this includes the naturalistic sculptures recovered from the Villa of the Papyricrept up on the visitors, making them sense the sudden extinction of life around Vesuvius as something at once uncannily unreal and forcefully true.

Another image of Pompeii-like pathos may be examined here to venture into the issues posed by the memory of Pompeii and Portici. Jean-Baptiste Stouf was a sculptor who, upon having won second medal in the Paris Academy's concours in 1769, set out to live in Palazzo Mancini with private support from July 1770 through to the spring of $1775 .^{41}$ This made him a contemporary of the high tide of "Neopaganism", and although a good number of pensionnaires found it difficult to obtain permissions to interrupt their Roman stay and visit Naples, a privately protected sculptor like him-

38. For the depressive confessions of Sergel and Thorvalsen, see LarSson, L.O., "Zwischen Depression...." For Géricault, see MicheL, R., Géricault: L'Invention du réel. Paris: Gallimard, 1992.

39. See ChARD, C., A Critical Reader of the Romantic Grand Tour: Tristes Plaisirs, Manchester: Manchester University Press, 2014, which includes an introduction on Engelbach.

40. Engelbach, L., Naples and the Campagna felice: in a Series of Letters, Addressed to a Friend in England, in 1802. London: R. Ackerman, 1817, p. 109.

41. SCHERF, G., "Une statuette en terre cuite de Jean-Baptiste Stouf au Nationalmuseum”, Art Bulletin of Nationalmuseum Stockholm, 20, 2013, pp. 27-36. 


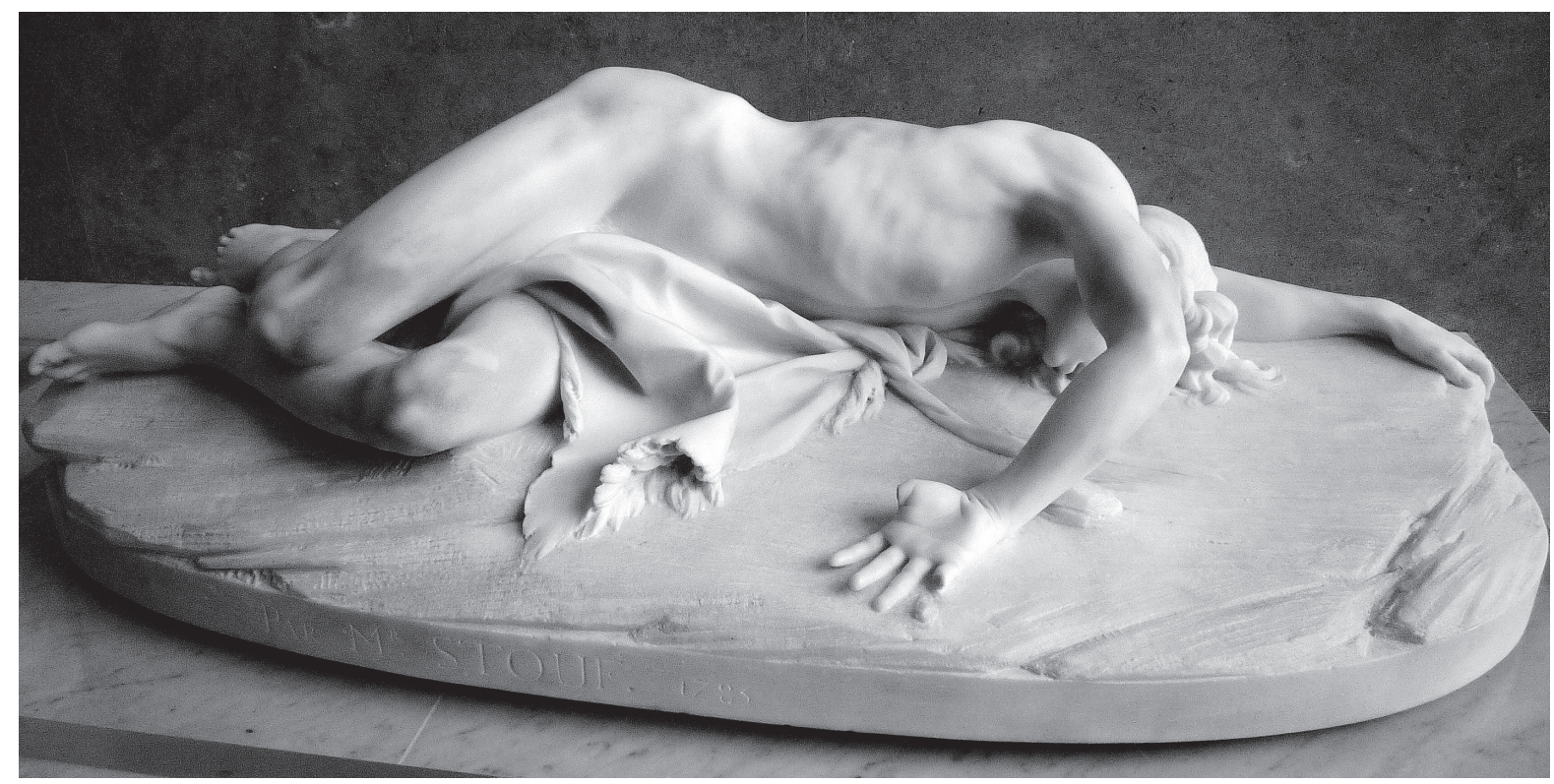

9. Jean-Baptiste Stouf Abel Expiring, 1785, marble, $102 \times 46 \mathrm{~cm}$. Musée du Louvre, Paris.

self would have been unrestrained in undertaking the journey. Upon his return to France, Stouf carved a shocking image of death, in his morceau de réception of Abel Expiring (figure 9).

Stouf had done away with heroic conventions that animated the series of death scenes of eighteenth-century sculptors' reception pieces. Similar to Sergel in his Drunken Faun, his attention is caught instead by the inarticulateness of the body no longer capable of holding itself together: that one tweaked arm, so gracelessly turned over in a painful contortion of itself, yet with no grimace or response on the face. There is in this sculpture a desolation that makes previous morceaux de réception seem operatic in comparison. ${ }^{42}$ Had Stouf somehow been reminiscing here on a victim of the Vesuvius? Had he perhaps seen one of those human moulds that were being recovered from the ashes from the 1750s onward, and which became part of the displays at Portici and Pompeii? In the Stouf, the skin is so tensely stretched over a ribcage, a pelvis and shoulder girdle, that it suggests the very frailty of life within it. Both Sergel's Dionysian Drunken Faun and the desperate Abel are closer to baroque martyrs than classical gods: they have such minutely carved skin, their bones and muscle show through almost menacingly, as if all gesture were insufficient. And their minds are dark, completely engulfed by a bodily state. If there is an aesthetic here, it is probably one of immediacy, and of shock. It may owe a debt to an epicurean walk through Pompeii. With no sure answer to a question of influence, these remarks must fade into speculation.

42. For the tradition of the morceau see StröвеLE, U., Die Bildhaueraufnahmestücke der Académie Royale de Peinture et de Sculpture in Paris 1700-1730. Petersberg: Michael Imhof, 2012; MacsotaY, T., The Profession..., chapter 1, and MacsoTAY, T.; Мүssок, J. (eds.), Die bildhauerischen Aufnahmestücke europäischer Kunstakademien im 18. und 19. Jahrhundert. Vienna-Cologne-Weimar: Böhlau, 2016. 